\title{
SWORD OF CHRIST. CHRISTIAN INSPIRATIONS OF POLISH SOCIALISM BEFORE THE JANUARY UPRISING
}

\author{
PIOTR KULIGOWSKI \\ piotr.kuligowski.1990@gmail.com \\ Adam Mickiewicz University in Poznań \\ Poland
}

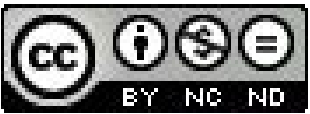

\begin{abstract}
The article presents the history of the Christian fraction of Polish socialism against the background of the era, from the very beginning until its end after the January Uprising. On the basis of the texts from the era the understanding of socialism, the principles of the program of Clusters of the Polish People and the anatomy of Fr. Piotr Ściegienny's conspiracy have been reconstructed. The text reproduces the utopian ideas of social reconstruction by Zenon Świętosławski and Ludwik Królikowski and based on these the text also shows the place of Christian socialism in the Polish socialist thought.
\end{abstract}

Key words: God, Christ, Christianity, socialism, utopia, property, community

A Cuban Poster by Alfredo Rostgaard of 1969 shows Christ carrying a rifle on his back. Others from the time of the revolutionary fever in Latin America show him in the likeness of the legendary Ernesto "Che" Guevara. These images, like almost every illustration of the Christian God-man as a partisan, are treated by many believers as iconoclasm. Similarly, in the bosom of modern socialism, or more broadly - the political left - references to Christianity are usually evaluated and even recall the evangelical roots of socialist thought. And although they reject this tradition as heterodoxy, and falling into antitheism, the left treats it as an embarrassing fault, you might want to come back to it - not least because it often is, which can be rejected by the hardliners, something of value. That - nomen omen - making some people indignant by the descent of the Left and Christianity is surprising in view of the facts. Therefore, before the appearance of the impact of Christianity on the Polish socialist thought one must, in order to clear up the point, paint the contemporary socio-political background.

The marriage of two now largely contradictory attitudes or philosophies developed a bold economic experiment in the second half of the eighteenth century, and though it can by no means be regarded as a strictly socialist move yet they engaged in a breach in the petrified feudal system, forming the basis on which new ideas soon flourished.

Perhaps the most eloquent example of business innovation is the Republic of Pavlovsk. In 1767 Fr. Paweł Ksawery Brzostowski acquired what was, at that time a small, "Earthly" mansion in Vilnius. Two years later he gave to the peasants who lived there, personal freedom and serfdom replaced enfranchisement. With time, 
the good - from the name of the holder named Republic of Pavlovsk - had gained self-government, arms, and a constitution approved by parliament less than a month before the Constitution of May 3rd. Peasants inhabiting this microscopic republic quickly attained a high degree of political and national consciousness, which gave rise to the mass insurrection of the November Uprising ${ }^{68}$.

\section{"GOD DID NOT CREATE STATES"}

Priest Paweł Brzostowski and others like him discovered that the potential inherent in the previously oppressed masses was strongly observed during the insurrection. That armed revolt is of utmost importance here, because - with the tide of ideas, typical of the French Revolution, reaching Polish borders - was a carrier, which permanently installed modern diplomacy on the Vistula, from the start weaving "leftism" on the one hand with Christianity ${ }^{69}$.

Already, therefore, during the last armed uprising in an independent yet, though much larger country, part of the clergy stayed on the side of the revolutionary ${ }^{70}$. One such sermon of a radical social pronunciation was given by Fr. Florian Jelski in the Capuchin Church on Miodowa street (Leśnodorski 1960, p. 230). In 1794, afterwards Warsaw patriotic pamphlets circulated, calling for a return to primitive Christian communities. The authors also criticized the union of most of the clergy, the Church hierarchy and the Roman Curia of the feudal regime, the despotism of kings and great lords (Leśnodorski 1960, p. 291). A similar overtonelies in an anonymous poem Doniesienie ludu Rzeczypospolitej wolnej, niepodległej z równa dla każdego w ogólności bezwzględna sprawiedliwościa (Report of the People of the Free, Independent and Equal for Everyone in General, Absolute Justice Republic):

"Don't falsify the message by proclaiming the will of God,

That innocent people have to endure slavery.

As how God is good, He did not create the states,

So people should not put up with tyrants" (Leśnodorski 1960, p. 274).

The enormous social energy, released in 1794, did not vanish with the tragic Finis Poloniae. Almost the day after the breakdown of the independent Republic a network of conspirators began to form, to which the invaders almost from the beginning had to respond with repression. It is significant that the first victims of the struggle for

68 The fate of the Republic of Pavlovsk is thoroughly considered in the monograph: J. Bartys (1982), Rzeczpospolita Pawłowska na tle reform włościańskich w Polsce w XVIII w., Warszawa (All translations by the author).

69 Quotation marks are necessary here, since - as demonstrated in his opus magnum, the Zarys dziejów polskiego socjalizmu Lidia and Adam Ciołkosz - division of the Polish political scene on the left and right side clarified only within the Polish Democratic Society (TDP). Members of TDP in 1834 during the voting began to break up the sides (See Ciołkosz 1966, p. 60).

70 The term "revolution" requires comment because of its ambiguity in the late eighteenth century, part of the general public understand, after all, the „revolution" as the reform of any government, while others wanted to see reform, going beyond the common forms of political (revolutionary in this approach would be any confederated parliament). More specific in that sentence, daring at that time, a definitional problem, was articulated by Franciszek Salezy Jezierski. He stated that the revolution offers freedom, human rights and the pursuit of happiness for all people of the country (See Leśnodorski 1960, p. 239-241). 
nationalism were executed pursuant to the judgment of the Austrian military court. By the 10th July 1797, the initiators of the clandestine armed organizations largely did homework on the recent insurrection, which showed clearly that without the support of the peasantry any uprising cannot be successful.

At the same time Napoleon created a check for military action, as well as a political weapon to improve the Poles. Created in Italy the legions became the great school of patriotism, linked closely - because of the geopolitical situation - with internationalism. Soon, caused by the "god of war" turmoil in Central Europe revealed the first attempt on home ground to raise the masses of peasants $^{71}$. Ludwik Gorzkowski followed it and claimed that "If the peasants once wanted, they'll do everything and would be free..." (Halicz 1955, p. 26). Despite his attempts, the plans of many thousands in popular uprising and its merging with the troops of Jan Henryk Dąbrowski were never fullfilled.

Soon came the fateful year of 1812, „,called by the people »crop year «, by soldiers, the "year of war «" (Miłkowski [Jeż]). The generation of the first Polish Socialists grew up in a strict sense in the shadow of that year, which marked the ultimate failure of the Polish dreams of the imminent resurrection of independent statehood. However, the memory of the achievements of the Napoleonic era, as well as a relatively recent annexation of the country, served as an inspiration. Dozens of underground organizations were created on Polish territory with the intent of not only the restoration of Poland, but also gave it specific, democratic character. This was the atmosphere of growing up of Polish pioneers of Christian socialism.

The storm of 1830 and 1831, attracted the restless spirits of those times. Bogdan Jański offered his services to the insurgent government in Warsaw - the first Pole, who accepted the principles of socialism in the Saint-Simonian version (Ciołkosz, Londyn 1966, p. 87-88). Uniquely in this matter was the fate of Tadeusz Kreppowiecki, who in 1831 fought at Stoczek, and a few months later he barely survived the siege of Warsaw (Kalbarczyk 1981a, p. 47-48). Similarly Stanisław Worcell, soon after the outbreak got to the Kingdom of Poland, where he established himself as a young and sensible politician (Kalbarczyk 1981b, p. 90.). Also, young mystics - Zenon Świętosławski and Ludwik Królikowski - expressed their support for armed action, placing themselves at the radical wing of the Patriotic Society (Kalbarczyk 1981c, p. 153, p. 195). Józef Ordęga was an insurgent who became well known for his valour in battle, he was decorated with a Gold Cross for his services. (Kalbarczyk 1981d, p. 284). Numbers let culminate the career of another revolutionary soldier, Leon Rzewuski who participated in the campaign of 1831, serving as an Adjutant to General Józef Chłopicki at the Battle of Grochów (Kalbarczyk 1981e, p. 371). All of them soon took their places in the pantheon of the first Polish Socialists.

\section{SOCIALISM MEANS BROTHERHOOD}

Shortly after the collapse many of the participants had, in the face of threats of reprisal, sought refuge in the West, primarily in France. There they encountered for the time mature, political ideas. Soon, even in 1831 (Żychowski 1976, p. 11),

71 Already in 1799 Ludwik Gorzkowski tried to organize the grid of conspiracy in the land of Siedlce (See Próchnik). 
was the appearance of the term "socialism" into national political thought, and this term was seen for the first time in the "Gazeta Polska" ("The Polish Newspaper"). It should be clear, however, definiens made for contemporary disciples of socialism many difficulties, as exemplified by numerous, vague explanations in articles of Polish left-wing columnists in the mid-nineteenth century.

Certainly, it is generally recognized that the 1830s, marked the early career of "socialism" in the Polish language, its concepts not yet understood as a comprehensive political proposal. It was more the attitude of opposition to individualism and selfishness, and therefore the same as altruism or collectivism. It was proven beyond doubt in the letter of the Municipality of Le Havre - "Zjednoczenie" ("The Association") - the pages of which were taken in 1841, foreign location test concepts. "Socialism" has been translated thus "społeczeńskość" (pro-social) and "individualism" to "misappropriation" and "osobnikowość" (private) (Ciołkosz 1966, p. 154). Socialism, therefore, had to mean as much the affirmation of the community, as depreciation of the individual.

It is widely understood that the contemporary mystic Ludwik Królikowski in 1850 in one of his texts suggested several possible explanations of socialism. His view was "active Christianity", "aware of what is most authentic", "striving for social order in which (...) all the elements (...) benefit all", "knowledge, how to make everybody happy", "most natural theory of social organization', "free anastomosis of all residents", "philosophy of the most positive", "politics most sublime", "religion purest and most heavenly" and finally "republicanism of the most perfect type" (Królikowski 1972, p. 590-591).

Also however the definition of Ludwik Królikowski explains none of the facts; we therefore, need to elaborate socialist prime factors and analyze the various political components.

The foundation of the contemporary Polish political thought, which in the main, protested against the existing order, leading to the lack of an independent Poland on the maps of Europe, gave a prescription for state reconstruction. Much of the revolutionary left, as indicated above perceived the peasantry as this factor, which was to prevail with victory in an armed confrontation with the aggressors. The development of that concept was an important reference point for worldrenowned scholar, historian, geographer, and numismatist, Joachim Lelewel. He affirmed the original gminowtadztwo (power of commoners), considering it to be a factor natural for the "Slavic element", but suffocated because of the licentiousness of the nobility. (Ciołkosz 1966, p. 89-103).

Socialists viewed the issue of Christian provenance differently. Gminowtadztwo ("power of commoners") in their opinion, is democracy, there was already present on the ground with the advent of Christ" ${ }^{72}$. Józef Ordęga in 1838, writing of the Deklaracja wystapienia z Towarzystwa Demokratycznego Polskiego (The Declaration

72 Ambiguous in this matter was the position of Zenon Świętosławski, which became a kind of primary between gminowtadztwo and democracy derived from the primitive Christian communities, claiming: "We are not only the voice of God, but the voice of the people Kołodziej was summoned to lead the government" and the "Christian faith wszechwtadztwo consistent with the people" (Świętosławski 1981a, p. 185). 
ofOccour with Polish Democratic Society) clearly expounded the thing. Like probably all contemporary Polish publicists, Józef Ordęga laid the groundwork for his historiosophic theories ${ }^{73}$. It found that all mankind by nature tends to God, and the Towarzystwo Demokratyczne Polskie (TDP) (Polish Democratic Society), cultivating the basis of the original gminowtadztwo (power of commoners), Poland goes back "to the social order of pre-Christian Slavs" (Ordęga 1981, p. 288). Critical of the rules of TDP also put into question the validity of the theoretical genetic structure of the alleged democratic Slavs claiming that their gminowtadztwo (power of commoners) "could be based only on strength " (Ordęga 1981, p. 289). In addition, Józef Ordęga attacked democrats for having - what today might give rise to considerable surprise - rejected Christianity, denying it as a feature of progress. Finally, he explicitly acknowledged that putting on a pedestal Slavic gminowładztwo (power of commoners), TDP rejected the main ingredient of democracy, namely the principle of "universal brotherhood, first revealed by Christ to humanity and to achieve the specified state" (Ordęga 1981, p. 289).

The dividing line between a secularized socialism of TDP and one surrounded by whims of mysticism such as socialism of Gromady Ludu Polskiego (Clusters of the Polish People) also concerned the approach to property. While the more moderate Democrats had an ambiguous approach to the problem, with most accepting individual property, the more radical crowd in the name of brotherhood preached the gospel principle of common ownership.

Christianity with socialism, nolens volens, already embarrassed the aforementioned Bogdan Jański. In 1834, succumbing to the influence of Adam Mickiewicz, while disappointing to the people standing at the head of the Saint-Simonians followers (with whom he initially sympathized), Bogdan Janski reconciled with the Church. And though he became famous later as the "apostle of Polish emigration", proclaimed by the views, society organized on Christian principles, were largely identical to the previously propagated saint-simonism following (Ciołkosz 1966, p. 89).

However, not all Polish socialists in the first decades of the nineteenth century treated the semi-theological argument completely seriously. Some of them used it as a mere political instrument used to validate and enhance communication. There is a very tempting hypothesis that this is how Christianity came to one of the greatest Polish writers of the mid-nineteenth century, pursued by the triad of the most prominent activists of TDP (Miłkowski [Jeż]), Stanisław Worcell. According to this condition he had his political ideas mixed up with Christianity as it were ex post, in order to render them in a more attractive linguistic form of propaganda (Urbankowski 1983, p. 82).

Also, not exactly clear in his position on religious matters was Adam Mickiewicz. Although his Lectures on Slavic Literature are simply overloaded with references to Christ and the Gospel, but a few years later, in the "Trybuna Ludów"

73 In a convincing way the interest of Polish nineteenth-century commentators on the historiosophy explained Bronisław Baczko: „The historical events - the loss of independence, Kosciuszko uprising, November Uprising - played a big role in the development of the nation (...). It was not only a theoretical problem. This was primarily a practical problem. It is no coincidence that almost without exception, all the political ideas of this period, tried to derive its program is the analysis of the past, with a particular historiosophical concept" (Baczko 1955, p. 25-326). 
("Tribune of the Peoples"), the bard wrote that "law should be atheist" (Mickiewicz 1956, p. 122).

A pragmatic approach to religion was held by one of the organizers of the Kraków revolution of 1846, Edward Dembowski. Although he probably was an atheist, in the face of impending defeat he did not hesitate to ask for help from clergy, and himself, with a crucifix in his hand, walked at the head of the procession, having to drag the peasants from surrounding villages to get attention. It proved a great social exposition Edward Dembowski - after all, on the grounds of the French quasi-religious Icarian movement, headed by Etienne Cabet and Ludwik Królikowski, had in the mid-nineteenth century, about 400000 followers (Sikora 1972, p. 17).

\section{“THIS IS THE FINAL STRUGGLE..."}

In contrast to Edward Dembowski, who used a cross only instrumentally, socialism and Christianity were truly connected in Fr. Piotr Ściegienny. He did not take part in the uprising because of residence in the Seminary, but it did not prevent him from absorbing democratic ideas. Captivated first by Les Livre du peuple by Hugues-Félicité-Robert de Lamennais, the young priest began to teach the peasants in the Lublin region, and from 1842 the network organized a conspiracy among them. This was the first such organization in the Polish lands, consisting solely of the people. The field of his activity was part of a wider conspiracy, which was to lead to an uprising in all three partitions (intended originally only to be in Kraków) (Limanowski 1920, p. 264).

Fr. Piotr Ściegienny in his propaganda used Złota książeczka (The Golden Book). It was a rigged Bull of Pope Gregory XVI, in the style of a pastoral letter. The recipients of its contents were to be not only the peasants, as Gregory XVI, greeting and apostolic blessing send "all the people, especially the farmers and craftsmen, soldiers and unhappy clerks" (Ciołkosz 1966, p. 259). Its main content was in the form of a contradiction, that the people had to accept slavery, poverty, hunger, cold, exploitation and ignorance of the will of God. On the contrary, the perpetrators had to be bad people, because God created man so that he could use all his gifts. Thus, Fr. Piotr Ściegienny in his message legitimized the need for redistribution of the original will of God.

Although the alleged pope in his edict condemned war, it is stated that "another war will have to take its place - a just war, because it would lead to defending life and liberty of his fellow men, and be raised in defense of rights and work " (Ciołkosz 1966, p. 260). This last fight was to take place by the will of God and bring the final abolition of serfdom, ecclesiastical rents and charges and to establish free education for peasant children. The enemies of the people in this battle were to be kings, lords, clerks, and some priests. It would be the only fair and last war, however, only possible if all the peasants, townspeople and the soldiers decided to jointly request it.

However conspiracy of Fr. Piotr Ściegienny did not result in armed struggle, because of the betrayal by one of the members was denounced, and the participants avoided severe penalties. Piotr Ściegienny was sentenced to the noose, but at 
the last minute it was commuted to flogging and life-long work in the Nerchinsk mines. The radical priest also had to watch the persecution of his brothers Dominik and Karol. The authorities were surprised by the size of the plot, many of its members - as deterrent to future engaging in this activity - received the penalty of one thousand lashes or deportation to Siberia (Limanowski 1920, p. 263).

The great significance Fr. Piotr Ściegienny is evidenced by the fact that Złota $k s i a \dot{z} e c z k a$ received a lot of popularity among the peasants and for many years its copies circulated in rural homes. The priest himself, returning under an amnesty of hard labor, was surrounded by Polish Socialists and hailed as a hero (Ciołkosz 1966, p. 265).

The organization of profiles somewhat similar to the conspiracy Fr. Piotr Ściegienny were Clusters of the Polish People, formed from peasant-soldiers in the United Kingdom. They consisted of former participants of the November Uprising, who after its fall were interned and detained in the fortresses of Prussia for two years for refusing to accept the Tsar's amnesty. In 1833 they were released and directed to America. Bad conditions for sailing meant that the ship Marianne carrying the indomitable people was diverted to Portsmouth. There was a rebellion and eventually the unwanted immigrants got the right to settle in the port city ${ }^{74}$.

The soldiers quickly found themselves in the sphere of influence of radical activists in exile, such as Tadeusz Krępowiecki or Stanisław Worcell, and joined the ranks of TDP. Soon, however, a split came between them and the Society and as a result the Polish exiles formed a Cluster Grudziąz. Shortly following to the caves in Portsmouth came their countrymen from the island of Jersey, who set up Cluster Humań (Temkinowa 1957, p. 21).

Two years after the founding of the first cluster, on $29^{\text {th }}$ November 1836, Polish soldiers in the barracks at Portsmouth approved its ideological declaration Do ludu polskiego na rodzinnej ziemi (To the Polish People on Native Soil). The authors of the text at the outset were identified as "yeomen of the Polish emigration"75.

The entire manifesto is filled with references to the saints, the Bible and Christ, but also the people and the common good. At its inception the Cluster's The Son of God was a poor social layman, who grew up among the poor, who bestowed gifts of bread and healing. Avoiding wealth and chasing the gold traders driving them from the temple. Therefore, the teaching of Jesus "was humiliation of those with lofty aims, and raising the little ones: making order on earth, was neither the rich nor poor, but that all men brake one piece of bread and the desire of one cup" (Do ludu polskiego na rodzinnej ziemi).

The authors of the manifesto for the purpose of mankind consider bringing God's kingdom on earth, which should be based on the principles of brotherhood, universal love and overall happiness. At the same time they believed these principles to be impossible to complete without listening to the teachings of the Gospel. Similarly, equality, according to the Cluster did, "not begin by human wisdom but with the eternal wisdom, and therefore only one way to understand it is permitted, it is just as Christ revealed it, and gave it to the apostles" (Do ludu polskiego na

74 Information on the history of the Polish People drawn from: Temkinowa 1962.

75 The text of the manifesto of the Clusters of the Polish People has been digitized and placed on the page: http:/ /lewicowo.pl/do-ludu-polskiego-na-rodzinnej-ziemi/, retrieved: 11/15/2011. 
rodzinnej ziemi). Freedom, equality and fraternity are even regarded as divine commandments, which false priests gave before shading their eyes against the people.

The text of the manifesto of the Clusters of the Polish People condemned social inequalities. Based on its analysis of reality of the watered down philosophy of early Christianity, the signatories of the document came to the conclusion that property is based on theft, and the wealth of one has to be associated with the poverty of the other. The owner of the land is, however, God, and therefore people, as "eunuchs", must manage it equitably - so that everyone had a plot that he would be able to cultivate the strength of his own hands. This view is associated with the metaphysical elevation of work, based on the teachings of St. Paul: "He who does not work, will not eat", "Work is the best prayer" (Do ludu polskiego na rodzinnej ziemi).

Clusters therefore wanted to bring heaven on earth. However, it was to be a paradise from which man has not already driven out God, just the opposite - he will restore it to a man. In their conceptions, therefore, was evident historical determinism. Therefore, the revolution was understood as "the Son of Man coming to his kingdom", which was crowned by the people - to put it bluntly - the slaughter of the nobility (Do ludu polskiego na rodzinnej ziemi).

\section{THE KINGDOM OF GOD ON EARTH}

With time - under the influence of Zenon Świętosławski, representing the "personality of the priest", (Kalbarczyk 1981g, p. 16-17) - the Polish People increasingly fell into religious mysticism. Stanisław Worcell, after leaving the clusters, decided to concretize a specific vision for the future social order. He took this vision from the Ustawy Kościoła Powszechnego (Law of the Universal Church) and extensive commentary on these. In 1844, after much deliberation, the text made by Zenon Świętosławski was signed by 49 clusters (Świętosławski 1957, p. 314).

Ustawy Kościoła Powszechnego was a retail image of the future constitution, which was to be universal and cover the whole world. The world that was to be dominated by a single religion, and become in this way the universal Church, divided into nations, provinces, districts and clusters. Capital of this superstate Zenon Świętosławski wanted to locate at the site of the present Suez Canal, and divided into circuits, those into the districts, those into communities, and those in clusters (Świętosławski 1981b, p. 164). The inventor treated this Administrative desiderata so seriously that in a comprehensive commentary followed to debate whether in future there should be one, big "Slavian" Republic, or should it rather be divided into the Republics of Poland, Czech, Hungary, etc. Finally, the first concept was upheld recognizing that such a creation comprised approximately 160 million people. That "Slavonia", which would cover the space "of the Oder to the Urals, from the Baltic Sea and the Arctic to the Black Sea and Adriatic", should be divided into approximately 200 provinces (Świętosławski 1981a, p. 174-175).

The vision was of man deprived of any individuality. He was above all to obey the Government, combined with the proviso that even the greatest merit does not receive either praise or any earthly reward. People in the universal Church would be brothers to one another to such an extent that they referred to each other as 
"you", rejecting any form of politeness. At the same time, nobody could call anything his own. Zenon Świętosławski in the apotheosis of the community goes even to the rejection of the community stating that everything belongs to God. In this utopian project and there is no place for any disobedience. Every wrong act had to be punished collectively. According to the author by an Act of the Universal Church a higher administrative unit must carry out the sanction of the dispersion of the population, erasing the language and names, and the destruction of all the tangible lower units which rebelled (Świętosławski 1981b, p. 157-158, 159, 162, 167).

In such a unified world, there could be no question of linguistic diversity. Raised up by his ardent patriotism and belief in the historic mission of Poles Zenon Świętosławski found that a common language should be the Polish language. In support of his choice he argued that the Polish people in Europe first started "the work of future ages", and the native language is supreme on the continent and "the most suitable for putting thoughts, feelings and ideas of future ages" (Świętosławski 1981a, p. 177).

"So, sacrifice, love, brotherhood, equality, unity, community property, nonhereditary offices, freedom, good full People and full power of the People, that is the principle from the beginning that we adopted, I am trying to bring about as closely as possible the transfer towards the Universal Church" (Świętosławski 1981a, p. 182) - said Zenon Świętosławski.

A parallel, though in many ways even more singular concept of social reconstruction of the final result was announced - claiming to be the depository of the will of Christ and the new messiah of the human race (Sikora 1972, p. 7) - Ludwik Królikowski. This vision is contained in the letter O Zjednoczeniu (About the Association) from 1845, published in "Polska Chrystusowa" ("The Polish Christ"). Despite the deep religiosity and even saturation of the textual references to the Bible, the author made an unconscious secularization of eschatology, focusing on building a paradise on earth. The paradise was open to anyone who received baptism and communion, and cleansed from sin through repentance (Królikowski 1845, p. 328329). Thus, in the vision of Ludwik Królikowski participation in the Association was in some way exclusive, because it was reserved for those who meet the census of religion and go in for deep expiation.

The law in this social order was to be the will of God, and his rule - evangelical brotherhood. Institutions and loss of the the sense of positive law, because God writes the law "at the heart of the people" (Królikowski 1845, p. 330). Despite bringing in such matters, Ludwik Królikowski insists on the establishment of highly specific managers, thus creating an extremely complicated bureaucratic machine, in which perhaps he sometimes loses track of the architect.

The lowest administrative unit of the Federation was to be a family, created by combining nine brothers in a bond of communion. Each of them has to get rid of individual liberty, to vest it in the collective. This would create a sequence of ten families, ten retinues - Cluster, ten Communities - Commune, ten of Communes Host, ten Hosts - Church, ten Churches - People, ten People - Nation, ten Nations - Strain, ten Strains - Wszechwtadztwo (full authority). A little further, however, Ludwik Królikowski says that the family should not be more than nineteen broth- 
ers and nineteen sisters (Królikowski 1845, p. 331). Thus, despite the earlier, rigid statement of the ten members of the lowest administrative unit, he allowed a certain plasticity of outlined communities.

Even stranger is the hierarchy, a service whose union was set up to organize the work of the spiritual and the secular. Thus, each family chooses from among themselves, Bogumił and Bogusław. Ten Bogumiłs and Bogusławs in their turn choose Chrystomił and Chrystosław. Ten Chrystomiłs and Chrystosławs of clusters choose Dobrosław and Dobromiła (Królikowski 1845, p. 333). And so on, up to the level of Wszemił, which was surrounded by divine love and ungodly villains (though in a different location Ludwik Królikowski states that they were to be murdered or expelled), and Wszewład, management of a criminal justice system (Królikowski 1845, p. 330). The two highest officials, however, only had to be "servants of servants" (servus servorum). None of them of his own volition could relinquish his duties, and for their exercise did not receive any material benefit.

A similar device to the illusions of the Union of the religious structure was that in which each member must be strictly obeyed, not only God but also the lay Prior.

\section{"DO NOT COME TO BRING PEACE"}

Visions of socialism by Zenon Świętosławski and Ludwik Królikowski are in some sense the culmination of efforts of the first generation of Polish Socialists, whose dominant paradigm was among other things evangelical fellowship coupled with the rejection of the institutional Church. These concepts apparently appear to be genetically anti-enlightenment, but in reality they reveal a number of theoretical similarities to the ideas of the times "era of lights". First of all, in both utopias can be seen the creation of a new order based on the decimal system, so typical for the French Revolution, where the creators wanted to resist, even the existing system of clock and calendar. Secondly, the Utopians succumbed to the enlightenment Christian belief that man is a plastic mass that can be almost a completely arbitrary form (Wielomski). What's more, man saw the potential of the Demiurge, through which the will of God can refute the old order and build a new one from scratch. Both in Zenon Świętosławski and Ludwik Królikowski strike radical detachment from the past and total future orientation (Świętosławski 1981b, p. 173-174). The rejection of the past in both the mystics is actually that the denial of any property (even common, for example, district) and believe that everything belongs to God. This follows from a deep concern for the common good and is the recipient, served in a sauce typically of socialist hatred for the oppressors, together with the Christian love of neighbour.

Of course, both O Zjednoczeniu and the Ustawy Kościoła Powszechnego, among many today can at best arouse interest because they characterize singularities. In any analysis of political thought it must be remembered that it always contains features characteristic of the era in which the future of the world is in question. Therefore, none of the modern Aristotelians require continuous breaking with the acceptance of slavery by the Stagirite - as the left does not have to always be ashamed of the racist, by today's criteria, statements of Karl Marx. It is analogous with the Christian-socialist utopias on Polish soil. Although they were not a dom- 
inant part of the then revolutionary discourse, their practical dimension, while recognizing the dialectical view of reality, cannot be overestimated. Utopias are in fact, peak sized dreams of a better and fairer society, aiming to explode ambient socio-political life, by creating a new quality (Tokarczyk 2010, p. 42).

And so, combining the philosophy of the Catholic peasantry and socialist-oriented the solution was innovative. However, in the rapidly changing situation in the nineteenth century, these ideas would soon be relegated to the background. Already in 1855 the members of the Clusters in London, in an open letter addressed to all the Polish emigration, made re-definitions of the word "socialism", which set new trends. They concluded that "Socialism [...] is a community of work and production and the division of labor according to physical strength and mental abilities" (Buszko 1957, p. 18). Border pillars, demarcating the new tendencies in the socialist movement, were the years of 1863-1871. During this period the Polish emigration, topped up after the defeat of the January Uprising wanderers, more commonly established a connection with the international socialist organizations. In 1864, the labor rally in solidarity with the January Uprising, formed a Workers' International Association, known as the First International. Quickly it pulled into their ranks the Polish socialists, among which the influence of Marxism grew more and more (Żychowski 1976, p. 43).

No wonder that, starting from 1866 in Geneva, "Gmina", referring to the ideology of the Fallen of the previous two decades of Clusters of the Polish People, experienced a wider readership (Buszko 1957, p. 56). A similar fate befell the book Opinions et croyances (Opinions and beliefs) by Leon Rzewuski. This item was to be the culmination of several years of work of the author, who tried to get to the basics of God, society and man. Published in 1869, the title of such eloquence, however, was already an anachronism (Kalbarczyk 1981h, p. 41).

This does not mean that a subsequent Polish thought makes no attempts at combining socialism and Christianity. After all, Father Stanislaw Stojałowski at one time a follower of Christian socialism was a pioneer of the peasant movement in Galicia. In the first decade of the twentieth century, another priest - Antoni Szech - articulated the socio-political program in a similar vein (Okraska 2011, p. 121). Edward Abramowski also advocated a highly valued social and moral message of Christianity, while rejecting its institutional dimension (Abramowski 1963, p. 121).

Christ, who says, "Do not come to bring peace but a sword" (Mt 10, 34), has inspired most of the first generation of Polish Socialists. As indicated, this resulted as much from a purely pragmatic approach to matters of faith, far from the real belief that Christians are the people that God has chosen as a tool not only for the absolute liberation of ourselves, but for the whole world. And although the plan failed its saviours, the kinship of the left and Christianity abounded in many interesting, innovative ideas.

\section{SOURCES}

Abramowski E. (1965), Zagadnienia socjalizmu [in:] Abramowski E., Filozofia Społeczna, Warszawa.

Do ludu polskiego na rodzinnej ziemi, http://lewicowo.pl/do-ludu-polskiego-na-rodzinnej-ziemi/, retrieved: 15.11.2011.

Królikowski L. (1845), O Zjednoczeniu [in:] „Polska Chrystusowa - pismo poświęcone zasadom społecznym" 4, Paryż. 
Królikowski L. (1972), Socjalizm [in:] Sikora A., Temkinowa H. (eds.), Ludwik Królikowski. Wybór pism, Warszawa.

Mickiewicz A. (1956), Socjalizm [in:] Mickiewicz A., Trybuna Ludów, Warszawa.

Ordęga J. (1981), Deklaracja wystapienia z Towarzystwa Demokratycznego Polskiego [in:] Kalbarczyk D. (ed.), Wskrzesić Polskę - zbawić świat. Antologia polskiej myśli spoteczno-radykalnej 1831-64, Warszawa.

Świętosławski Z. (1981a), Komentarz do ustaw Kościoła Powszechnego [in:] Kalbarczyk D. (ed.), Wskrzesić Polskę - zbawić świat. Antologia polskiej myśli społeczno-radykalnej 1831-64, Warszawa.

Świętosławski Z. (1981b), Ustawy Kościoła Powszechnego [in:] Kalbarczyk D. (ed.), Wskrzesić Polskę zbawić świat. Antologia polskiej myśli społeczno-radykalnej 1831-64, Warszawa.

Zespół Biblistów Polskich z inicjatywy Towarzystwa Świętego Pawła (eds.) (2006), Pismo święte Nowego Testamentu, Częstochowa.

\section{BIBLIOGRAPHY}

Baczko B. (1955), Poglady społeczno-polityczne i filozoficzne Towarzystwa Demokratycznego Polskiego, Warszawa.

Bartyś J. (1982), Rzeczpospolita Pawłowska na tle reform włościańskich w Polsce w XVIII w., Warszawa.

Buszko J. (1857), Narodziny ruchu socjalistycznego na ziemiach polskich, Kraków.

Ciołkosz L. \& A. (1966), Zarys dziejów socjalizmu polskiego, vol. I, Londyn.

Dyksztajn Sz., Narkiewicz-Jodko W. (1904), Polski socyalizm utopijny na emigracyi (dwie rozprawy), Kraków.

Halicz E. (1955), Rola nurtu plebejskiego w powstaniach polskich XIX w., Warszawa.

Kalbarczyk D. (1981a), Tadeusz Krępowiecki [in:] Kalbarczyk D. (ed.), Wskrzesić Polskę - zbawić świat. Antologia polskiej myśli spoteczno-radykalnej 1831-64, Warszawa.

Kalbarczyk D. (1981b), Stanistaw Worcell [in:] Kalbarczyk D. (ed.), Wskrzesić Polskę - zbawić świat. Antologia polskiej myśli społeczno-radykalnej 1831-64, Warszawa.

Kalbarczyk D. (1981c), Zenon Świętostawski [in:] Kalbarczyk D. (ed.), Wskrzesić Polskę - zbawić świat. Antologia polskiej myśli społeczno-radykalnej 1831-64, Warszawa.

Kalbarczyk D. (1981d), Ludwik Królikowski [in:] Kalbarczyk D. (ed.), Wskrzesić Polskę - zbawić świat. Antologia polskiej myśli spoteczno-radykalnej 1831-64, Warszawa.

Kalbarczyk D. (1981e), Józef Ordęga [in:] Kalbarczyk D. (ed.), Wskrzesić Polskę - zbawić świat. Antologia polskiej myśli społeczno-radykalnej 1831-64, Warszawa.

Kalbarczyk D. (1981f), Leon Rzewuski [in:] Kalbarczyk D. (ed.), Wskrzesić Polske - zbawić świat. Antologia polskiej myśli społeczno-radykalnej 1831-64, Warszawa.

Kabalarczyk D. (1981g), Trzy wersje gromadzkiego socjalizmu [in:] Kalbarczyk D. (ed.), Wskrzesić Polskęzbawić świat. Antologia polskiej myśli społeczno-radykalnej 1831-64, Warszawa.

Kalbarczyk D. (1981h), Liberałowie wśród radykałów [in:] Kalbarczyk D. (ed.), Wskrzesić Polskę - zbawić świat. Antologia polskiej myśli społeczno-radykalnej 1831-64, Warszawa.

Leśnodorski B. (1960), Polscy jakobini. Karta z dziejów insurekcji 1794 roku, Warszawa.

Limanowski B. (1920), Stuletnia walka narodu polskiego o niepodległość, Warszawa.

Okraska R. (2011), Za szczęście wasze i nasze, czyli polska teologia wyzwolenia, „Nowy Obywatel” 3.

Sikora A. (1972), Królikowski czyli szaleństwa konsekwencji [in:] Sikora A., Temkinowa H. (eds.), Ludwik Królikowski. Wybór pism, Warszawa.

Temkinowa H. (1962), Gromady Ludu Polskiego (zarys ideologii), Warszawa.

Temkinowa H. (1957), Wstęp z historii Gromad Ludu Polskiego [in:] Temkinowa H. (ed.), Lud Polski. Wybór dokumentów, Warszawa.

Tokarczyk R. (2010), Wspótczesne doktryny polityczne, Warszawa.

Urbankowski B. (1983), Kierunki poszukiwań. Szkice o polskich socjalistach, Warszawa.

Żychowski M. (1976), Polska myśl socjalistyczna XIX i XX wieku, Warszawa.

\section{NETOGRAPHY}

Miłkowski Z. (Jeż T.T.), Sylwety emigracyjne, http:// literat.ug.edu.pl/jez/002.htm, retrieved: 15.11.2011. Próchnik A., Początki socjalizmu polskiego, http://lewicowo.pl/poczatki-socjalizmu-polskiego/, retrieved: 23.04.2012.

Wielomski A., Oświecenie, http://metapedia.konserwatyzm.pl/wiki/O\%C5\%9Bwiecenie, retrieved: 15.11.2011. 